\title{
Imaginary Controversists: Abraham Gómez Silveyra and the Theologians of the Huguenot Exile*
}

\author{
Carsten L. Wilke** \\ Central European University \\ ORCID ID: https://orcid.org/0000-0001-9785-208X
}

In the Huguenot refugee community in The Netherlands, known as a hotbed of the early Enlightenment, literary interest in Judaism was ubiquitous, yet actual Dutch Jews were relegated to a marginal position in the exchange of ideas. It is this paradoxical experience of cultural participation and social exclusion that a major unpublished source allows to depict. The ex-converso Abraham Gómez Silveyra (1651-1741), a merchant endowed with rabbinic education and proficiency in French, composed eight manuscript volumes of theological reflections in Spanish literary prose and poetry. This huge clandestine series, which survives in three copies, shows the author's insatiable curiosity for Christian thought. While rebutting Isaac Jacquelot's missionary activity, he fraternizes with Pierre Jurieu's millenarianism, Jacques Basnage's historiography, and Pierre Bayle's plea for religious freedom. Gómez Silveyra, however, being painfully aware of his voicelessness in the public sphere, enacts Bayle's utopian project as a closed performance for a Jewish audience.

KEYwords: Amsterdam; Enlightenment; Jewish-Christian Polemics; Tolerance.

Controversistas imaginarios: Abraham Gómez Silveyra y los teólogos del exilio HUGONOTE.- En la comunidad de refugiados hugonotes en los Países Bajos, conocida como un semillero de la Ilustración temprana, el interés literario por el judaísmo era omnipresente, a pesar de que los judíos holandeses estuviesen relegados a una posición marginal en el intercambio de ideas. Es esta experiencia paradójica de participación cultural y exclusión social la que permite plasmar una importante fuente inédita. El ex

* This article is based on a lecture that I gave on November 15, 2017, at the Faculty of Catholic Theology of the University of Vienna in the context of the conference "Can Polemics Innovate? Change and Continuity in Jewish-Christian Polemics from Late Antiquity to Modernity" organized by Károly Dániel Dobos and Gerhard Langer. My research has benefitted from a fellowship at the "Maimonides Centre for Advanced Studies (MCAS)-Jewish Scepticism" at the University of Hamburg. I thank Gad Freudenthal and David B. Ruderman for their critical comments on the manuscript. Unless otherwise indicated, all translations in this article are my own.

**wilkec@ceu.edu

Copyright: (C) 2021 CSIC. This is an open-access article distributed under the terms of the Creative Commons Attribution 4.0 International (CC BY 4.0) License. 
converso Abraham Gómez Silveyra (1651-1741), un comerciante dotado de educación rabínica y dominio del francés, compuso en español ocho volúmenes manuscritos de reflexiones teológicas en prosa y poesía literarias. Esta enorme serie clandestina, que sobrevive en tres copias, muestra la insaciable curiosidad del autor por el pensamiento cristiano. Mientras refuta la obra misionera de Isaac Jacquelot, confraterniza con el milenarismo de Pierre Jurieu, la historiografía de Jacques Basnage y la llamada de Pierre Bayle por la libertad religiosa. Dolorosamente consciente de su falta de voz en la esfera pública, Gómez Silveyra encarna el proyecto utópico de Bayle como una actuación cerrada para una audiencia judía.

PALABRAS ClaVE: Amsterdam; Ilustración; polémica judeocristiana; tolerancia.

\section{Was there a Jewish-Christian dialogue in the Early ENLIGHTENMENT?}

One of many marketing frauds in eighteenth-century publishing, and a rather shameless one at that, is the title page of a 1770 publication announcing that the reader could find within its book's contents a debate about religion between Viscount Bolingbroke and the famous Jewish polemicist Isaac Orobio, a doctor who was transformed here into a rabbi. ${ }^{1}$ Whoever was lured into buying this book had to discover that neither Bolingbroke nor Orobio appear anywhere inside the volume, which is a reprint of the Entretiens (Conversations) that the French Protestant émigré Mathurin Veyssière La Croze had anonymously published in 1711. The Entretiens evoke the dialogue between the narrator and a Jew called Moyse Aboab, whose personality, travels, philosophical interests, and religious doubts are developed in colorful detail in the course of his constant interaction with Christians in Livorno, Amsterdam, and Suriname. ${ }^{2}$

Jewish literary personae who engage with Enlightenment philosophers also appear elsewhere in early eighteenth-century literature. Most famously, the Marquis d'Argens detailed in his Lettres juives (Jewish

${ }^{1}$ Entretiens sur divers sujets d'histoire et de religion entre Mylord Bolingbroke et Isaac d'Orobio, rabin des juifs portugais à Amsterdam (n.p., 1770); see Yosef KAPLAN, From Christianity to Judaism: The Story of Isaac Orobio de Castro (Oxford: Littman Library of Jewish Civilization, 1989) pp. 466-467.

2 [Mathurin Veyssière LA CROzE], Entretiens sur divers sujets d'histoire, de litterature, de religion et de critique (Cologne: Pierre Marteau, 1711). 
Letters, 1736-1742) the views and opinions of Aaron Monceca, a freethinking Ottoman Jew visiting Paris ${ }^{3}$ and a successor to the philosophizing Persian Muslims who people Montesquieu's Lettres persanes (Persian Letters, 1721). Historians have contextualized D'Argens's novel within the Enlightenment interest in anti-Christian polemics and polemicists. ${ }^{4}$ In two articles, Jonathan Israel asked the question of whether the literary fiction of cultivated Jews conversing with Christians about religion had any factual basis in the intellectual life of the period. His answer, prudently affirmative, ${ }^{5}$ joins a well-established historiographical narrative according to which the early years of the eighteenth century brought a closer interaction of Jews with their neighbors and softened confessional boundaries. ${ }^{6}$ Richard Popkin even tried to present intense Jewish-Christian "joint ventures" as a trigger of European modernity. ${ }^{7}$ In the years "of the late seventeenth and early eighteenth centuries," David Ruderman writes, "Jews and Christians were encountering each other in public and private places, in intellectual forums, and in radical and spiritualist movements." 8

3 Jean-Baptiste DE BOYER, Marquis d'Argens, Lettres juives, ou correspondance philosophique, historique, et critique, entre un Juif voyageur à Paris et ses correspondans en divers endroits (The Hague: Pierre Paupie, 1736-1737. 6 vols.), and Lettres cabalistiques, ou Correspondance philosophique, historique \& critique entre deux Cabalistes, divers esprits élémentaires et le seigneur Astaroth (The Hague: Pierre Paupie, 1737-1738. 4 vols.). The author published both works in progressively augmented editions until 1742 .

4 Adam Sutcliffe, Judaism and Enlightenment (Cambridge: Cambridge University Press, 2003) pp. 209-212.

5 Jonathan I. IsRael, "Was There a Pre-1740 Sephardic Jewish Enlightenment?," Arquivos do Centro Cultural Calouste Gulbenkian 48 (2004) pp. 3-20 and "Philosophy, Deism, and the Early Sephardic Enlightenment," in The Dutch Intersection: The Jews and the Netherlands in Modern History, ed. Yosef Kaplan (Leiden: Brill, 2008) pp. 173-201. Israel's conclusion was endorsed by Shmuel FeInER, The Origins of Jewish Secularization in Eighteenth-Century Europe, trans. Chaya NAOR (Philadelphia: University of Pennsylvania Press, 2010) p. 88.

${ }^{6}$ Azriel Sсноснат, 'Im hillufei tekufot: Reshit ha-haśkalah be-yahadut Germanyah (Jerusalem: Mossad Bialik, 1960), and Shmuel FeINER, 'Et hadashah: Yehudim ba-me'ah ha-shemoneh 'eśreh, 1700-1750 (Jerusalem: Zalman Shazar Center, 2017) pp. 53 and 147.

7 Richard PopkIN, "Introduction," in Jewish Christians and Christian Jews from the Renaissance to the Enlightenment, ed. Richard PoPKIN (Dordrecht: Kluwer, 1994) pp. 1-9: 5.

${ }^{8}$ David B. Ruderman, Early Modern Jewry: A Cultural History (Princeton, NJ: Princeton University Press, 2010) pp. 159-160. 
Natalie Zemon Davis once asked me whether Moyse Aboab's life story, which enters prominently into the scope of Israel's mentioned articles, might be sifted for elements of an actual transcontinental biography. The question is difficult to answer. On the one hand, the external framework of Aboab's story is authenticated by many amazingly concrete clues fitting all we can know about the Sephardi diaspora of his time. On the other hand, while the scenery of the Entretiens is well in line with historical evidence, the plot is not. Very few cases of direct Jewish-Christian exchange on religion, whether oral or written, are known from the decades that follow the 1685 controversy between Philipp van Limborch and Isaac Orobio, ${ }^{9}$ a debate that the fraudster of 1770 still evokes as if he had no newer precedent to reach back to. The medieval genre of public theological disputation had died out ${ }^{10}$ after Protestant missionaries stopped seeing Jews as dangerous rivals and reduced them to a mere target of systematic education. ${ }^{11}$ In a 1677 bylaw, the Sephardi community of Amsterdam forbid its members, with severe penalties, to engage in any cross-confessional "conversations and debates, both those that are held in public and those that are held in secret." 12 A new form of Jewish-Christian conversation emerged only in 1753, when the physician Aaron Salomon Gumpertz brokered the young Moses Mendelssohn's encounter with Gotthold Ephraim Lessing and other Berlin intellectuals. ${ }^{13}$ By 1762, Isaac Pinto's polemics with Voltaire had opened up a different cycle of public controversy.

9 Kaplan, From Christianity to Judaism, pp. 270-284.

10 A private disputation held at the Prince Elector's court of Hanover in July 1704 is the exception that confirms the rule. See Zvi Asaria, Die Juden in Niedersachsen, von den ältesten Zeiten bis zur Gegenwart (Leer: Rautenberg, 1979) pp. 34-36.

11 On this turn, see Martin FriEdrich, Zwischen Abwehr und Bekehrung: Die Stellung der deutschen evangelischen Theologie zum Judentum im 17. Jahrhundert (Tübingen: Mohr, 1988); Christopher Clark, The Politics of Conversion: Missionary Protestantism and the Jews in Prussia 1728-1941 (Oxford: Clarendon Press, 1995), and Jutta Braden, Konvertiten aus dem Judentum in Hamburg 1603-1760: Esdras Edzardis Stiftung zur Bekehrung der Juden von 1667 (Göttingen: Wallstein, 2016).

12 Yosef Kaplan, "Between Calvinists and Jews in Seventeenth Century Amsterdam," in Conflict and Religious Conversation in Latin Christendom: Studies in Honour of Ora Limor, eds. Israel Jacob Yuval and Ram Ben-Shalom (Turnhout: Brepols, 2014) pp. 277-303: 297.

13 Gad Freudenthal, "Aaron Salomon Gumpertz, Gotthold Ephraim Lessing, and the First Call for an Improvement of the Civil Rights of Jews in Germany (1753)," AJS Review 29:2 (2005) pp. 299-353. 
Peter van Rooden argued that the crisis of humanist learning during the first half of the eighteenth century indeed rarified Jewish-Christian scholarly encounters and deepened the social segregation between the two republics of letters. ${ }^{14}$ Adam Sutcliffe likewise observed that "the strengthening Enlightenment gravely sapped Jewish intellectual and cultural selfconfidence. After the 1680s, the Jewish contribution in the Early Enlightenment was essentially limited to disembodied texts." 15 Shouldn't we suspect, then, that Moyse Aboab was as much invented from scratch as the Bolingbroke-Orobio debate? Yosef Kaplan suggested a more complex explanation for the dearth of trustworthy sources on direct communication. It might well be that "quite a few Sephardi Jews of Amsterdam continued to hold lively discussions with Christian scholars," but that, due to the community ban, such debates "were not, of course, public, and they were not publicized." ${ }^{16}$ The lingering uncertainty about this topic justifies the search for new documentary evidence that I will now undertake.

\section{Abraham Gómez Silveyra’s life, work, AND opinions}

In his bold effort to prove the historicity of the encounters depicted in the Entretiens and the Lettres juives, Israel claimed two extraliterary parallels from the first half of the eighteenth century. The first is a rabbi in London, David Nieto (1654-1728), who wrote against Christian theology (whether or not he had any direct religious argument with Christians remains a matter of conjecture); ${ }^{17}$ and the second is a private scholar in Amsterdam, Abraham Gómez Silveyra (1651-1741), on

14 Peter van Rooden, "Sects, Heterodoxies, and the Diffusion of Knowledge in the Republic of Letters," in Commercium litterarium: La communication dans la république des lettres 1600-1750, eds. Hans Bots and Françoise WAQUET (Amsterdam: APA, 1994) pp. 51-64, and "Willem Surenhuys' Translation of the Mishna and the Strange Death of Christian Hebraism," in Reuchlin und seine Erben: Forscher, Denker, Ideologen und Spinner, eds. Peter SCHÄFER and Irina WANDREY (Ostfildern: Jan Thorbecke Verlag, 2005) pp. 97-110.

15 Sutcliffe, Judaism and Enlightenment, p. 116.

16 Kaplan, "Between Calvinists and Jews," p. 298.

17 David B. Ruderman, "Jewish Thought in Newtonian England: The Career and Writings of David Nieto (In Memory of Jacob J. Petuchowski)," Proceedings of the American Academy for Jewish Research 58 (1992) pp. 193-219: 217. 
whose historical personality the literary figure of Moyse Aboab is said to be modeled: "'Moise Aboab' is a kind of 'Nathan der Weise' avant la lettre, who besides being in part a literary echo of Orobio, also portrays the Amsterdam Sephardi poet and publicist Abraham Gómez Silveyra." The latter, "in the years 1698-1700, entered into controversy with the Huguenot preacher Isaac Jacquelot over whether Jesus really was the Messiah." ${ }^{18}$ Gómez Silveyra thus appears as the missing link for Jewish-Christian interaction between Orobio and Mendelssohn and as the central proof for Israel's claim that "there were indeed early eighteenth-century Sephardi Jews in northwest Europe who believed that they could actively contribute to the spread of enlightenment and toleration by helping undermine respect for the Christian gospels, Christian theology, and ecclesiastical authority (and possibly also rabbinic prestige and status)." 19

It is true that Abraham Gómez Silveyra clandestinely wrote down arguments against a book by Jacquelot, but this does not warrant the conclusion that the Jewish polemicist was engaged in a controversy with this Huguenot preacher. Israel, so it seems, has derived his thesis from previous guesswork by Martin Mulsow, according to which Gómez Silveyra and Jacquelot confidentially communicated with each other as well as with "a mix of Huguenots, Socinians, Arminians and Jews in Amsterdam and London. These people often knew one another." ${ }^{20}$ To support his idyllic vision of cross-religious intermingling around 1700, Mulsow reproduced the title page of a Spanish manuscript written by Abraham Gómez Silveyra against Jacquelot. He had unfortunately not consulted the text itself, where the author declares from the first page that not a word of his refutation ever reached Jacquelot, since he, as a Jew, could not dare to enter a debate with a member of the ruling faith. On the basis of this passage, Harm den Boer has already pointed out that

18 Israel, "Philosophy, Deism, and the Early Sephardic Enlightenment," p. 184.

19 Israel, "Philosophy, Deism, and the Early Sephardic Enlightenment," p. 198.

${ }^{20}$ Martin Mulsow, Moderne aus dem Untergrund: Radikale Frühaufklärung in Deutschland 1680-1720 (Hamburg: Felix Meiner, 2002) pp. 54-56, and Enlightenment Underground: Radical Germany, 1680-1720, trans. H. C. Erik Midelfort (Charlottesville: University of Virginia Press, 2015) pp. 34-35. 
the debate between the Huguenot and the Jew only took place in the latter's literary imagination. ${ }^{21}$

If Abraham Gómez Silveyra's work was not the product of a social "mix" but of an imposed isolation, which place, then, did this author really occupy within the changing religious world of his age? The eightvolume series, which he named Silveyradas after himself but which is signed with his initials only, is dated to the year 1700 on the title pages of most of the volumes, ${ }^{22}$ and the same year is also given in most of the secondary literature. In reality, Gómez Silveyra has antedated his volumes, except perhaps the first one, and it is possible to determine from internal evidence that he must have written them much later, namely during the decade from 1715 to 1725 . Produced during a protracted period and covering more than four thousand quarto pages, the Silveyradas are arguably the most extensive text to have ever been composed by a Jew against Christianity. This collection is the last major item of an important clandestine literature that circulated in the Sephardi communities of former conversos in the Atlantic world. ${ }^{23}$ At the same time, its composition is the earliest occasion on which Jewish literature has come to deal with such topics as Richard Simon's Bible criticism, Pierre Bayle's skepticism and plea for toleration, Montesquieu's Persian Letters, the English deists, and incipient freemasonry. A fluent reader of French, the author processed a vast number of books, newspapers, and pamphlets, hoping to explain to a Sephardi audience the onslaught of

${ }^{21}$ Harm DEN BoER, "Le 'contre-discours' des nouveaux juifs: Esprit et polémique dans la littérature des juifs sépharades d'Amsterdam," in Les Sépharades en littérature: Un parcours millénaire, ed. Esther BENBASSA (Paris: PUPS, 2005) pp. 47-65: 59, and "La controverse religieuse d'Abraham Gómez Silveira contre Isaac Jaquelot: Le discours jocoserio d'un exilé dans la République des Lettres," in Esilio e persecuzione: Sguardi incrociati su ebrei e ugonotti, ed. Myriam SILVERA (Ariccia: Aracne, 2016) pp. 67-81: 75 .

22 The date "Año 1700" appears not only on the title page of the first volume, where it may be correct, but also on the title pages of the second, third, fourth, and preliminary volumes, which in reality were written decades later. Only the Libro Quinto bears the date "Año 1725."

${ }^{23}$ Carsten L. WiLke, "Clandestine Classics: Isaac Orobio and the Polemical Genre among the Dutch Sephardim," in Isaac Orobio: The Jewish Argument with Dogma and Doubt, ed. Carsten L. WILKE (Berlin: De Gruyter, 2018) pp. 57-76. 
critical rationalism on the religious faiths, as well as the infighting among adherents of the latter.

The huge manuscript series was never printed and is extant today in three copies, which are held respectively by the Ets Haim Library of Amsterdam, the Dutch Royal Library at The Hague, and Yeshiva University Library in New York. Single volumes from the series are in possession of the Bibliotheca Rosenthaliana at the Amsterdam University Library, the John Rylands Library in Manchester, and the Jewish Theological Seminary in New York. ${ }^{24}$ The work deterred scholars by its sheer size and by its unstructured and repetitive-yet eloquent and wittystyle, in which prose and verse sections alternate to form a humorous and at times deliberately absurd sort of erudition. Harm den Boer and I are now working on a critical edition and study of the entire eight volumes, which are of undeniable value for the history of both JewishChristian relations and Hispanic letters in the early modern period.

The author was a relative of the Portuguese converso physician Miguel de Silveyra, who served the king of Spain and the viceroy of Naples while acquiring literary fame with an epic poem on the Maccabean Revolt. ${ }^{25}$ Abraham's cultural background was similarly complex. He was born as Diego Gómez Silveyra in Arévalo, Old Castile, in 1651 and grew up in Madrid as a Catholic until the age of twenty, when he

${ }^{24}$ I will quote the eight volumes of the Silveyradas (which I enumerate here in the chronological order of their composition) from the following manuscripts: Libro Primero from The Hague, Koninklijke Bibliotheek [henceforth: KB] 75 F 5; Libro Segundo from KB 75 F 6; Libro Terzero from Amsterdam, Ets Haim [henceforth: EH] 48 B 15; Libro Quarto from EH 48 B 17; Libro Anteprimero from EH 48 A 18; Libro Quinto from EH 48 A 22; Libro Mudo from EH 48 B 18; Dialogos Theologicos from EH 48 B 13. None of the extant manuscripts gives the full series. If counted in the above chronological order, the Ets Haim Library has a heterogeneous series of volumes three to eight (1,682 folios), while the manuscripts of The Hague and Yeshiva University, Ms. 1374, are continuous copies of, respectively, volumes one to seven (2,071 folios) and volumes one to six (1,369 folios). The John Rylands Library, Gaster Ms. 1594, possesses the first volume (285 folios). Digital reproductions are available online for all the manuscripts of the Ets Haim collection and for the Yeshiva University copy.

25 Silveyradas, Libro Terzero, fol. 6r: "mi tio el gran silveyra;" Silveyradas, Libro Quarto, fol. 465r: "el Gran Miguel de Silveyra mi tio;" and with more precision in Silveyradas, Libro Anteprimero, fol. 21v: Miguel de Silveyra was the cousin and brotherin-law of Diego Méndez Jiménez, a brother of his grandfather. 
embraced Judaism in France and changed his name to Abraham. ${ }^{26}$ With his mother and sister, he moved onward to the Jewish community of Amsterdam and received a rabbinical education at its orphanage. When he graduated in 1676, he was already a successful public preacher, but he decided shortly later to settle in Antwerp, where he lived for many years engaged in business and, occasionally, in poetry. He returned to Amsterdam as a merchant and married Ester Franco da Silva in 1694. Having lost his wife in 1714, he led a solitary and quiet life until his death at age ninety. ${ }^{27}$ For decades, his major concern was to dispose of his vast stock of free time: "I am a gentleman who eats his lunch at home. I write because I do not have anything else to do and because I do not want to have any other business." 28 Most likely, he derived his income from stock-exchange gains. One can sense the emotion in his words when he comments on the financial crazes that were the Mississippi and South Sea bubbles in $1720 .{ }^{29}$

Though his passion for theological argument and satirical poetry made Gómez Silveyra religiously suspect among the Amsterdam Jews, ${ }^{30}$ the opinions that he expresses throughout his work manifest a staunch

${ }^{26}$ In his work, Gómez Silveyra mentions the early stations of his life: Arévalo in Silveyradas, Libro Quarto, fol. 3r, Madrid and France in Libro Quinto, fol. 125v, and Dialogos, fol. 185r. Based on sources from Amsterdam, scholars have dated his birth to 1656; see Kenneth Brown and Harm DEN BoER, El Barroco sefardi: Abraham Gómez Silveira (Arévalo, prov. de Ávila, Castilla 1656 - Amsterdam 1741). Estudio preliminar, obras líricas, vejámenes en prosa y verso y documentación personal (Kassel: Reichenberger, 2000) pp. 13 and 19. The Spanish parish records, however, prove that Diego, son of Luis Méndez de Silveyra and Ana Jiménez, was baptised on May 26, 1651; see Archivo Diocesano de Ávila, Registros parroquiales de San Miguel (Arévalo), Bautismos 1588-1664, fol. 47r (Genealogical Society of Utah Film 1327119, image 368). Gómez Silveyra possibly cheated about his age when he was admitted as a student at the Jewish orphanage.

27 Brown and Den Boer, El Barroco sefardi, pp. 19 and 23.

${ }_{28}$ Silveyradas, Libro Terzero, fol. 314r; similar affirmations in Libro Segundo, fols. 318r, 543v and 314r; Libro Terzero, fols. 1r and 152v; Libro Quarto, fols. 18v and 240v; Libro Anteprimero, fols. 9r-v, 65v, 230r and 268v, and Libro Quinto, fol. 197v.

29 Silveyradas, Libro Quarto, fol. 122v; see also the allusion to the stock exchange in Silveyradas, Dialogos, fol. 65r.

30 Brown and den BoEr, El Barroco sefardí, pp. 253-255. 
Jewish orthodoxy: ${ }^{31}$ The Torah has been given once and for all and "everything new is false"-this constantly repeated conviction is his main argument against the Christian dogmas. ${ }^{32}$ Our Sephardi polemicist thus anticipates literally the slogan "everything new is forbidden by the Torah," which was coined by Moses Sofer in 1819 and which has become the mantra of today's ultra-orthodox. ${ }^{33}$ For good reason, Henry Méchoulan called Gómez Silveyra "doubtlessly an intolerant, if not a fanatic Jew." ${ }^{34}$ In the Maimonidean tradition, his extreme rabbinic antimodernism harmonizes with a rationalist vision of the future. If ever the Christians took the Reformation of the Church seriously, they would have to adhere to Noachism, that is, the kind of natural monotheism that Mosaic Law imposes on non-Jews: "They should believe in One God, observe only the natural precepts that He has given to all [humanity] and abandon everything new, intruded, unreliable, superstitious, and false." 35

31 Alexander Even-Chen ("Peshat ha-mikra kimkor lewada'ut datit bekhitvei 'Avraham Gomez Silveyra," Pe 'amim 60 [1994] pp. 20-31) misrepresents Gómez Silveyra as a scripturalist of Protestant and Cartesian inspiration, while in reality this author insists throughout his work on the necessity of the rabbinic tradition for the correct understanding of the Mosaic text.

32 Silveyradas, Libro Quarto, fol. 17r: "Devemos detestar todo lo nuevo, contrario a lo que Dios en su Ley clara, perfecta y eterna enseña. Entendéis esto? Pues esto es lo que digo. Digo una cosa mil vezes, porque yo no tengo más que una cosa que dezir." $\mathrm{He}$ indeed repeats the idea over and over again. See there, fols. $2 \mathrm{v}, 8 \mathrm{v}, 37 \mathrm{v}$ ("todo lo nuevo es falso en materia de religión"), 50r ("No puede ser sagrado ni divino nada moderno"), 54v, 56r, 66r, 76v, etc.

33 In Hebrew he-hadash assur min ha-Torah bekhol makom; see Maoz KAHANA, Me-ha-Noda' bIhuda la-Hatam Sofer: Halakha ve-hagut mul 'etgarei ha-zeman (Jerusalem: Zalman Shazar Center, 2015) pp. 349-351.

${ }^{34}$ Henry MÉchoulan, "Réflexions sur une alternative récurrente aux XVI et XVII siècles: tolérance et intolérance," in La formazione storica della alterità: Studi di storia della tolleranza nell'età moderna offerti a Antonio Rotondò, eds. Henry Méchoulan, Richard H. Popkin, Giuseppe Ricuperati, and Luisa Simonuti (Florence: Olschki, 2001. 3 vols.) vol. II, pp. 805-828: 823.

35 Silveyradas, Libro Quarto, fol. 86r. On early modern Noachism, see Herman Prins Salomon, "Baruch Spinoza, Ishac Orobio de Castro and Haham Mosseh Rephael d'Aguilar on the Noahites: A Chapter in the History of Thought," Arquivos do Centro Cultural Português 14 (1983) pp. 253-286, and Lea CAmpos Boralevi, "Mitzvoth Beneh Noah: Il diritto noaico nel dibattito seicentesco sulla tolleranza," in La formazione storica della alterità, vol. II, pp. 473-494. 


\section{French Protestants and Portuguese Jews in Amsterdam}

Gómez Silveyra's interaction with Christianity needs to be located in a precise historical context, namely the years that saw the expansion of Huguenot diaspora culture. ${ }^{36}$ After the revocation of the Nantes Edict (1685), approximately 180,000 Protestants left the lands of Louis XIV, about one-third of them finding asylum in the Dutch Provinces. At the turn of the eighteenth century, Huguenots counted for about one-quarter of the population of Amsterdam. Here, the French Calvinists fleeing the Sun King's violent persecutions encountered Portuguese Jewish refugees of the Inquisition and Polish Jewish survivors of the Cossack massacres. Charged with theological meaning, the Jewish diaspora became a role model for the newly formed Huguenot dispersion that was struggling to elaborate its theological and political self-definition. There were reasons for both groups to feel a deep empathy for one another, since both had been uprooted from their homelands by the excesses of political Catholicism, both faced the challenges of a diaspora situation, both explored new capitalist ventures, and both looked for answers in the same biblical texts. However, Huguenots had enjoyed full citizens' rights in the city of Amsterdam since 1705 and in the entire Dutch Republic since 1715, while Jews remained a protected minority. Both groups' entangled history shows the effects of economic, political, and ideological competition, a "proximate otherness" that considers the other both as a point of identification and as a threat to one's own integrity. The incisive and ambivalent reflections of French Protestants on Jewish history and tradition have been studied by Myriam Yardeni ${ }^{37}$ and subsequent scholars. ${ }^{38}$

36 The following figures are taken from Myriam YARDENI, Huguenots et juifs (Paris: Champion, 2008) p. 95.

37 YaRdENI, Huguenots et juifs, and her earlier article "Yahadut wihudim be'einei ha-golim ha-proțesțantiyim ha-tsorfatiyim she-beHoland (1685-1715)," Mehkarim betoledot 'am Yiśra'el we'Erets Yiśra'el 1 (1970) pp. 163-185; English translation in Myriam YARDENI, Anti-Jewish Mentalities in Early Modern Europe (Lanham, MD: University Press of America, 1990) pp. 179-199.

${ }^{38}$ Hubert Bost, "La persécution, preuve paradoxale de l'élection: Lectures huguenotes du 'Vieux Testament' en contexte de répression," in Bible, histoire et société: Mélanges offerts à Bernard Roussel, eds. R. Gerald HobBs and Annie Noblesse-RoCHER (Turnhout: Brepols, 2013) pp. 25-43, and Michaël GreEn, "Jews and Other Re- 
Several studies have explored a bilateral approach; ${ }^{39}$ and in a recent edited volume, Myriam Silvera outlined a program for a histoire croisée approach to this topic. ${ }^{40}$

The Jewish theological engagement in this relationship, to the knowledge of which I want to contribute here, cannot be separated from the intra-Huguenot debate on the interpretation of Christian history. Some French Protestant theologians believed, at least for apologetic purposes, that they and their Catholic persecutors were part of a common Christian hegemony over the world; others, inversely, viewed history as the desperate defense of a final faithful remnant against the assaults of an idolatrous papacy. The latter expected that the fight would soon be rewarded by God's redemptive intervention, which had been announced by the Hebrew prophets. ${ }^{41}$ While Pierre Jurieu (1637-1713) had chosen this apocalyptic path and, as a consequence, claimed a common platform with the Jews, Isaac Jacquelot (1647-1708) reasserted the triumphalist narrative and insisted on the basic community with the Catholics. In the latter's Dissertations sur le Messie (Dissertations on the Messiah), which he published in 1699, ostensibly as a missionary treatise directed toward the Jews, he assured readers that all biblical prophecies had already been fulfilled, either by the Jewish restoration of the Second Temple or by the subsequent global spread of Christianity. ${ }^{42}$

ligious Confessions as Seen in the French Language Periodicals Published by the Huguenots in the United Provinces (1680-1715)," in Scripta Judaica Cracoviensia 15 (2018) pp. 25-46.

39 Rena Fuxs-Mansfeld, "Une rencontre en exil: Huguenots et juifs dans la République néerlandaise, 1685-1715," in Conflits politiques, controverses religieuses: Essais d'histoire européenne aux $16^{e}-18^{e}$ siècles, eds. Ouzi Elyada and Jacques Le BRUn (Paris: Éditions de l'École des Hautes Études en Sciences Sociales, 2002) pp. 59-76; on Gómez Silveyra, see here pp. 70-71, and Patrick CABAnel, "Israélitisme et huguenotisme: Les minorités religieuses françaises et la gestion de l'identité," in Un modèle d'intégration: Juifs et Israélites en France et en Europe (XIX ${ }^{e}-X X^{e}$ siècles), eds. Patrick CABANEL and Chantal Bordes-Benayoun (Paris: Berg, 2004) pp. 267-281.

40 Myriam Silvera, (ed.), Esilio e persecuzione: Sguardi incrociati su ebrei e ugonotti (Ariccia: Aracne, 2016).

${ }^{41}$ FuKs-Mansfeld, "Une rencontre en exil," pp. 62-64.

42 Isaac JACQUELOT, Dissertations sur le Messie, où l'on prouve aux Juifs que JésusChrist est le Messie promis et prédit dans l'Ancien Testament (The Hague: Étienne Foulque, 1699). 
4. Isaac Jacquelot as the target of the Silveyradas, volumes one TO FOUR

While being obliquely directed to Jurieu, the Dissertations address contemporary Jews explicitly. Jacquelot acknowledged that the Dutch Jews had contributed to the help and support that Huguenot refugees from France had received in the Netherlands, and he sympathized deeply with the Jewish experience of being victims rather than authors of intolerance. ${ }^{43} \mathrm{He}$ thus started his proselytizing in a friendly tone, giving his potential Jewish interlocutors all kinds of guarantees of freedom from religious coercion. ${ }^{44}$

Abraham Gómez Silveyra would later present his immense manuscript collection as a refutation of this one book, the Dissertations. ${ }^{45}$ The first two of the eight volumes offer a Spanish translation of Jacquelot's text, which is given piecemeal with interspersed comments, the result being a fictional dialogue between the Huguenot author and his Jewish reader. Under the mask of a figure called "S.," the latter politely reciprocated Jacquelot's sympathy: "I recognize the pious compassion with which you speak of our misfortunes; and with this confidence I humbly entreat you to allow me that I offer my reply to your benevolence, not in order to persuade you, nor to persuade anyone to believe what I say, but only to justify what I believe." ${ }^{46}$ His Christian adversary "M. J." apes the real Monsieur Jacquelot by assuring his love for the Jewish people and by vowing to "attract your minds with good arguments instead of torturing your bodies with atrocities." ${ }^{47}$ Discussing Jacquelot's arguments in the order of the Dissertations, the speakers "S." and "M.

43 Yardeni, Huguenots et juifs, p. 153.

44 Jacquelot, Dissertations sur le Messie, fol. *5r.

45 Silveyradas, Libro Anteprimero, fol. 1r: "la Respuesta humilde que haze A.G.S. en cinco Libros al que hizo el Doctissimo Yshac Jacquelot."

46 Silveyradas, Libro Primero, fol. 2r.

47 Silveyradas, Libro Primero, fol. 2v; see also Carsten L. WILKe, "Torah Alone: Protestantism as Model and Target of Sephardi Religious Polemics in the Early Modern Netherlands," in Polemical Encounters: Christians, Jews, and Muslims in Iberia and Beyond, eds. Mercedes García-Arenal and Gerard Wiegers (University Park: Pennsylvania State University Press, 2019) pp. 357-376. 
J." conduct their Ciceronian dialogue henceforth in a familiar, sometimes ironical, but always benevolent tone. Gómez Silveyra generally quotes Protestant authors with approbation when they assert the principle of Scripture's absolute authority and present the Pentateuch as the only universally shared core of scriptural revelation.

The dialogue opposing "S." to "M. J." continues all the way through Gómez Silveyra's second volume, which was apparently finished in 1715. ${ }^{48}$ It contains frequent references to the writings of another Huguenot author, Jacques Basnage (1653-1723), ${ }^{49}$ whose six-volume publication The History and Religion of the Jews from Jesus Christ to the Present appeared in Rotterdam in 1706-1707 and became the basis of the nine-volume History of the Jews that followed a decade later. ${ }^{50}$ What attracts the Jewish controversist in Basnage's history is its secular approach, which discarded the providential economy of deicide and punishment and developed a non-theological analysis of diaspora as the social and economic mode of organization adopted by a dispersed community. At the end of the second volume, Gómez Silveyra discovered an even more powerful Huguenot ally, Pierre Jurieu. He accused Jacquelot of having silenced the arguments that Jurieu had presented in favor of the literal understanding of the biblical prophecies concerning the exile and redemption of the Jews, arguments that led to the conclusion that most of the messianic events were still to happen. ${ }^{51}$ To the dismay of his fellow pastors and his friend Pierre Bayle, Jurieu had rallied millenarianism and emitted the prophecy of an imminent fall of the Church

48 Silveyradas, Libro Segundo, fol. 514r: "oy se cumplen 1715 años que vino, y se fue."

49 Silveyradas, Libro Segundo, fols. 501v, 534r and 540v; Silveyradas, Libro Quarto, fol. 30v; Silveyradas, Libro Quinto, fols. 4r, 6r and 94v, and Silveyradas, Libro Mudo, fols. 74r-76r.

50 Basnage, L'Histoire et la religion des Juifs, depuis Jésus-Christ jusqu'à présent. Pour servir de supplement \& de continuation á l'Histoire de Joseph (Rotterdam: Reinier Leers, 1706-1707. 6 vols.); Second edition Histoire des Juifs, depuis Jesus-Christ jusqu'à présent. Pour servir de continuation á l'Histoire de Joseph (The Hague: Scheurleer, 1716. 9 vols.). On Basnage's views of the Jews, see SutcLiffe, Judaism and Enlightenment, pp. 81-89, and Michael BREnNER, Prophets of the Past: Interpreters of Jewish History (Princeton, NJ: Princeton University Press, 2010) pp. 18-20.

51 Silveyradas, Libro Segundo, fols. 529r-536r. 
of Rome in his L'Accomplissement des prophéties (Accomplishment of the Prophecies, 1686). Isolated in his own camp, the Protestant visionary had sought out the Jews as his new allies. He introduced his publication with a letter in which he invited Jewish scholars to read his book and promised that they would not find anything offensive to their creed. ${ }^{52}$

Throughout his many volumes, Gómez Silveyra voiced a great admiration for Jurieu. A Jewish scholar could not have written a more truthful account of the biblical message, he claimed: "This is a robust theologian, who does not run after the fashions. He argues in the good old style, that is, in the Mosaic way, without embracing fantasies and without putting on any allegorical makeup. He reads the book of God as if there were no other books in the world to distract him. And whoever reads Scripture like him will understand what God says, how He says it, and how He wants to be understood by all men." Jurieu's printed apology, where he sought to dispel any suspicions of Judaizing, was in Gómez Silveyra's eyes only an exercise in dissimulation: "A blind man can see that he says this to satisfy his parishioners and to avoid showing himself in too Jewish a garb. Judaism is saintly and good, but it is certainly not fashionable." 53

Echoing a powerful early modern idea, ${ }^{54}$ Gómez Silveyra was convinced that with some goodwill it would be possible to work out a common theological platform uniting Jews with millenarian Protestants like Jurieu: "The differences that we have are not of any importance. It is irrelevant whether Jesus Christ has to return to the world or whether God will send someone else to be the Messiah. If we leave this [disagreement] aside, it would be easy, if ever one would wish, to overcome the resentment on excellent terms, end disputes, and make peace among all nations." The Christians themselves admit that Jesus defended the Torah at least in its natural law aspects: "If you say that the only thing Jesus

52 JURIEU, L'Accomplissement des prophéties ou la delivrance prochaine de l'Église (Rotterdam: Abraham Acher, 1686).

53 Silveyradas, Libro Segundo, fols. 529r-v, 531v and 535v-536r; similarly Silveyradas, Libro Quinto, fols. 141v, 182v and 185v.

${ }^{54}$ Matt Goldish, Richard H. Popkin, and James E. Force, (eds.), Millenarianism and Messianism in Early Modern European Culture (Dordrecht: Kluwer, 2001-2013. 4 vols.). 
Christ did was annul the ceremonies, I respond that the ceremonies are not your business anyway. You may enjoy all the bacon that you can eat, God has not given to you any prohibitions in this respect." ${ }^{55}$ In other words, Christianity does not presuppose the annulment of Mosaic Law; on the contrary, Christians and Jews can commonly venerate it and observe their respective portions of it: the former only the natural law portions, and the latter all the commandments, with both being united in a common hope for a messianic age in which all men would be good and wise. It would be relatively easy, Gómez Silveyra thinks, to negotiate a theological peace treaty at a "free council" that Jews and Christians could convene jointly. But unfortunately, such a peace is unlikely since the errors will always prevail over the truth in controversy. The conclusion is that "this great enterprise of illuminating the minds and of writing the sacred truths in the hearts is reserved to God, according to the divine oracles. Any intent to convince one another and to reach a consensus among all would be in contradiction with the divine decree." 56 There may at least be "truce and good correspondence" (treguas y buena correspondencia) if all admit that confessional boundaries must be left where they are. ${ }^{57}$

But how can the modest hope for "good correspondence" be fulfilled if it does not even exist among members of the same church? On his manuscript pages, Gómez Silveyra ironically asked Jacquelot why he did not make any mention of Jurieu's books and why he had never traveled the short distance from The Hague to Rotterdam to meet the author. ${ }^{58}$ By suspecting his adversary's willingness to enter into a real dialogue, Gómez Silveyra gave a surprising proof of his own isolation from the Huguenot scholarly world, since in 1715, when he was writing, both Jacquelot and Jurieu were long deceased, and the former had left The Hague for Berlin already in 1702. Only in 1725 would the clandestine polemicist finally realize that "Monsieur Jurieu died a few years ago in Rotterdam; he was a profound writer, very well inclined towards the

\footnotetext{
55 Silveyradas, Libro Segundo, fol. 538v.

56 Silveyradas, Libro Segundo, fols. 543v-544r.

57 Silveyradas, Libro Segundo, fol. 539v.

58 Silveyradas, Libro Segundo, fol. 533r.
} 
Jews." ${ }^{59}$ With a more ambivalent judgment, a later volume of the Silveyradas calls Jurieu "a very thoughtful man, albeit very unstable, and in his prophecies, he was a monumental crackpot" (grandissimo loco) ${ }^{60}$

As for Jacquelot, Gómez Silveyra continued addressing him directly in his third volume, which he wrote in $1719,{ }^{61}$ still unaware of the fact that his interlocutor was no more among the living. He confessed to Jacquelot that he had planned to send him by mail the two-volume refutation of the Dissertations, but he had never dared to do so because of the social gulf that separated him, the Jew, from the pastor. "You can write, since you are comfortably at home in your country, while I cannot even breathe, because I am an exile without a home and without an inch of land that I can call my own." ${ }^{62} \mathrm{He}$ thus decided to postpone his conversation with Jacquelot to the afterlife, though he did not expect any free speech there either: "If you get hold of this letter in the valley of Josaphat, you will tell me in whispers whether the Jews are as ugly as one paints them." ${ }^{63}$ On several later occasions, he tried to explain his fear of letting Jacquelot know about the thousands of pages that he had penned against him: "Monsieur Jacquelot produces a book in order to attack Judaism; and I produce another one in order to defend it. He does not point a dagger to my chest to make me believe him; on the contrary, he kindly asks me to reply to him. But whereas he publishes his book, because this is his country, I hide mine, because I am in captivity." ${ }^{6}$

In the fourth volume, which was composed in $1720,{ }^{65}$ Gómez Silveyra reports how, with twelve years' delay, he incidentally learned about Jacquelot's demise. "I have just read in the Gazette," he writes, "that my man has died, Isaac Jacquelot. I regretted this greatly, because

59 Silveyradas, Libro Quinto, fol. 227r.

60 Silveyradas, Libro Anteprimero, fol. 251r.

${ }^{61}$ Silveyradas, Libro Terzero, fol. 148v, gives the date of July 1, 1719. The composition of volumes two and three must have overlapped. The finished second volume is mentioned at the beginning of the third (fol. $1 \mathrm{r}$ and $2 \mathrm{v}$ ), yet the third volume is frequently quoted in the second (fols. 322v, 325v, 353v, 356v, 366r, 370r, 476v and 508r).

62 Silveyradas, Libro Terzero, fol. 1r; also in Den BoER, "La controverse religieuse," p. 74.

63 Silveyradas, Libro Terzero, fol. 1r-v.

64 Silveyradas, Libro Anteprimero, fol. 130r.

65 Silveyradas, Libro Quarto, fol. 122v gives the date of June 15, 1720. 
I wanted to write to him and would have desired to be in communication with him. Indeed, one needs to acknowledge with gratitude his sincere and zealous wish to teach the Jews. As he won't be able to write anything else, I can also stop writing now." ${ }^{66}$ This was an empty threat because Gómez Silveyra found ways to continue his imaginary dialogue. He argued with Jacquelot's posthumous publications ${ }^{67}$ as well as with those of other Huguenot theologians, such as Jacques Abbadie (1654-1727), the author of an apologetic work on the truth of the Christian religion, ${ }^{68}$ and Pierre Allix (1641-1717), who used biblical allegory and Christian Kabbalah in order to prove the Trinity against the Unitarians. ${ }^{69}$ According to Gómez Silveyra's interpretation of these intra-Christian controversies, the dogmatic evolution of the various churches followed the pattern of a star-like deviation from a common Jewish root. This model allowed Gómez Silveyra to legitimize rabbinic Judaism both with the scripturalism of the Protestants and the traditionalism of the Catholics.

\section{IMAGINARY CONTROVERSY AND ITS RULES IN THE FOUR SUPPLEMENT VOLUMES}

Shortly after completing his four-volume series, Gómez Silveyra came across a clandestine Portuguese pamphlet against the Inquisition, the Noticias Recônditas (Hidden News), which Rabbi David Nieto had published anonymously in London in $1722 .{ }^{70}$ As this impressive text encouraged him to push the argument for interreligious tolerance further, he was fas-

${ }^{66}$ Silveyradas, Libro Quarto, fol. 131v.

67 Silveyradas, Libro Quarto, fols. 131v-144r, on Isaac JacQuelot, Traité de la verité et de l'inspiration des livres de vieux et du nouveau Testament (Rotterdam: Gaspard Fritsch, 1715).

68 Silveyradas, Libro Quarto, fols. 65r-76v; on Jacques ABBadie, La Vérité de la religion chrétienne (Rotterdam: R. Leers, 1684).

69 Silveyradas, Libro Quarto, fols. 122v-126r; on Pierre Allix, Réflexions sur les livres de l'Écriture Sainte, pour établir la vérité de la religion chrétienne (Amsterdam: Paul Marret, 1689. 2 vols.).

70 Silveyradas, Libro Anteprimero, fol. 9v; on [David NieTo], Noticias recónditas y póstumas de los procedimientos de las Inquisiciones de España y Portugal con sus presos (Villafranca [i.e., London], 1722). 
cinated by the idea of giving rules to the debates that he anticipated in his imagination. He undertook a new volume, which he conceived as a "preliminary book" (libro anteprimero) under the title "General Rules for All Kinds of Religious Controversies." He wrote it in 1723, as he indicated toward the end of the volume. ${ }^{71}$ Gómez Silveyra argued polemically against the commonly held conviction that religious unity is the necessary condition for social peace. He fully subscribed to the Protestants' condemnation of religious coercion and persecution, ${ }^{72}$ and he exemplified his point through data on the Iberian Inquisitions, including references to the persecution that his mother and her family had suffered in Madrid in 1635. ${ }^{73}$ Silveyra took issue with the authorities of Catholic thought, first and foremost with Augustine, documenting the impact of the latter's repressive ideas through much of Catholic pulpit oratory in France, Spain, and Portugal. Against this Catholic tradition of enforcing salvation, Jewish and Protestant theologians formed a common front. ${ }^{74}$

In his refutation of Augustine's apology of religious persecution, Gómez Silveyra quoted abundantly from Pierre Bayle (1647-1706), more precisely from the latter's Philosophical Commentary on the Verse "Compelle Intrare" (1713). ${ }^{75} \mathrm{He}$ had read this book immediately after its posthumous

71 Silveyradas, Libro Anteprimero, fol. 252r: "en este instante 20 de Julio 1723."

72 Geoffrey Adams, The Huguenots and French Opinion, 1685-1787: The Enlightenment Debate on Toleration (Waterloo, ON: Wilfrid Laurier University Press, 1991).

73 Silveyradas, Libro Anteprimero, fol. 21v (with the wrong year of 1645); Silveyradas, Libro Mudo, fol. $218 \mathrm{v}$, both passages being edited side by side in the article of I. S. RÉvAH, "Le procès inquisitorial contre Rodrigo Méndez Silva, historiographe du roi Philippe IV," Bulletin hispanique 67:3-4 (1965) pp. 225-252: 246-247; see also Shalom Rosenberg and Alexander Even-Chen, "Coplas filosóficas de Abraham Gómez Silveyra," Revue des études juives 153 (1994) pp. 327-351: 328, and Brown and DEN BoER, El Barroco sefardi, p. 14.

74 Henry Méchoulan, "La liberté de conscience chez les penseurs juifs d'Amsterdam au XVII siècle," in La Liberté de conscience (XVI ${ }^{e}-X V I I I^{e}$ siècles), eds. Hans R. Guggisberg, Frank Lestringant and Jean-Claude Margolin (Geneva: Droz, 1991) pp. 217-233, and "A propos de la liberté de conscience: remarques sur un manuscrit d'Abraham Gomes Silveyra," in Nature, croyance, raison: Mélanges offerts à Sylvain Zac, ed. Michèle CRAMPE-CASNABET (Fontenay-aux-Roses: École Normale Supérieure, 1992) pp. 25-41.

75 Silveyradas, Libro Anteprimero, fols. 65v-66r, 72r, 73v-74r, 88r-90r, 128v, 161v, 231r, 236r and 241v; on Pierre BAYLE, Commentaire philosophique sur ces paroles de 
publication and noted in his second volume how much the utopian vision of a free society, in which every religion would be allowed to argue and teach, emboldened him in his imaginary fight with Jacquelot. ${ }^{76}$ In the "preliminary book," he discussed Bayle's famous call to tolerate the cults of all inhabitants who believe in God, practice a religion, and do not betray their authorities. The Jewish author fully shared Bayle's conviction that those who do not admit foreign creeds into their midst reveal their doctrinal inferiority-they do not know to defend their doctrine by other means: "The use of violence, of torturers and dragoons manifests intellectual weakness." 77 For good reason, the expression "los berdugos y los dragones" lumps together the enemies of the Jews and the Huguenots with one single execration. Gómez Silveyra repeatedly expresses a deep sentiment of solidarity when he speaks of "the oppression to which they submit the Protestants in France" 78 and gathered their community with his own into a single group of victims: "Let the Castilians, the Portuguese and the French know that the persecutions against Jews, Huguenots etc. are detested even by many of their doctors and popes." 79 In the Netherlands, the two immigrant groups were united by their common patriotism. The new media and forms of communication were developed in particular by the Huguenots and could comfortably be consumed by a Francophone Jew such as Gómez Silveyra.

Gómez Silveyra connects the postulate of toleration to the uncertainty of dogmatic claims and to the observation that "every religion, even that of the Popists, believes that it is the true one and that all the others are heretical and barbaric." 80 But as it turned out, Bayle's Jewish reader was not ready to endorse a radically formalist justification of the liberty of conscience. ${ }^{81} \mathrm{He}$ tirelessly repeats his claim that liberty of conscience,

Jésus-Christ "Contrains-les d'entrer" ou Traité de la tolérance universelle (Rotterdam: Fritsch et Böhm, 1713).

76 Silveyradas, Libro Segundo, fol. 343r, and Libro Anteprimero, fol. 248r.

77 Silveyradas, Libro Anteprimero, fol. 66r.

78 Silveyradas, Libro Anteprimero, fol. 128r.

79 Silveyradas, Libro Anteprimero, fol. 242r.

80 Silveyradas, Libro Anteprimero, fol. $128 \mathrm{v}$.

${ }^{81}$ Lidia Denkova, (ed.), Genèse de la tolérance: de Platon à Benjamin Constant: Anthologie de textes (Paris: UNESCO, 2001) pp. 179-180: "toute action, qui est faite contre les lumières de la conscience, est essentiellement mauvaise." 
according to Bayle, would protect false religious convictions exactly to the same extent as it protects true ones. ${ }^{82}$ This maxim, Gómez Silveyra argues, would oblige the state to tolerate the worst tyrannies and crimes; it would be like "saying that those who believe that it is allowed to kill, steal, commit adultery etc. have to be allowed to follow their misguided opinion." Religious conscience can only be protected "if the error is not a gross one." 83 His own compromise formula would accept all the historical religions, as long as they do not spread their doctrines by means of violence, but it would persecute "without mercy" anyone who tries to live without a religious faith. In his view, these libertines are of three classes: the atheists who have no god, the deists who have no religion, and the Sadducees who do not believe in the afterlife. ${ }^{84}$ The truce among all believers, for which our Jewish polemicist hoped, should also function as a universal alliance against unbelief. Though Gómez Silveyra was progressively disquieted by the threat posed by "Spinozists and libertines," ${ }^{5}$ he did not enter the ranks of the apologists of religious faith. There is no direct quotation of Spinoza or, for that matter, any non-theist in the entire eight volumes, as if their tenets did not even merit a refutation. The radical critique of religion is insistently talked about, but it is never addressed.

When he wrote his sixth volume (the fifth of his own count) in $1725,{ }^{86}$ Gómez Silveyra had become an avid reader of the newly established literary journals. His interest turned with force toward the writings of English religious thinkers such as Daniel Whitby (1638-1726), Robert Jenkin (1656-1727), William Wotton (1666-1727), Thomas Bennet (1673-1728), and Benjamin Hoadly (1676-1761), whose work he could read in French translation in the Bibliothèque angloise, a periodical publication by a Huguenot refugee in London, Michel de La Roche. ${ }^{87}$

82 Silveyradas, Libro Anteprimero, fols. 88r, 161v, 231r and 236r.

83 Silveyradas, Libro Anteprimero, fol. 89 r.

${ }^{84}$ Silveyradas, Libro Anteprimero, fol. 241r-v.

85 Silveyradas, Libro Anteprimero, fols. 44r, 76r and 248r.

86 Silveyradas, Libro Quinto, fol. Ir: "Año 1725”; fol. 139v: "ya van 1725 años"; fol. 181r: "agora 10 de marzo 1725"; fols. 221-rv and 225v: "oy 10 de abril de 1725 ", and fol. 227r: "este de 1725."

87 Bibliothèque angloise, ou histoire littéraire de la Grande Bretagne (Amsterdam, 1717-1728). Gómez Silveyra frequently refers to this periodical (e.g., in Silveyradas, 
In 1725, the Silveyradas were launched for manuscript circulation as a six-volume series. ${ }^{88}$ About one decade later, the author decided to add a supplemental volume with the raw material of his writing, an alphabetical anthology of quotations, mostly of biblical or Christian origin. ${ }^{89}$ The volume was conceived as a "mute book" (libro mudo), where "the author repeats the foreign opinions and falls silent." However, having completed the alphabet, the author's voice breaks out anew, thrilled by the quickly changing state of world affairs that transpired in the journals. In December 1736, Gómez Silveyra noted with enthusiasm the pioneering initiative of Father Benito Jerónimo Feijóo to introduce the Enlightenment in Spain, his native country; there were even rumors about the separation of the Spanish Church from Rome. ${ }^{90}$ On the last pages of the volume, written during the spring and summer of 1739 , he was fascinated with the appearance of the freemasons and acclaimed this order as the new common religion of mankind. ${ }^{91}$ While in his earlier work he had based his idea of a religious consensus on the acceptance of the Pentateuch as moral authority by all creeds, he was now increasingly interested in the Socinian, Muslim, Chinese, and finally masonic alternatives to scriptural confessionalism. But on the whole, his early or, one might say, earliest Jewish Enlightenment thought was in no way interested in dethroning religion, but rather sought to buttress its reign through the selective appropriation of critical reason.

Gómez Silveyra mentions the "mute book" in another supplemental volume of his Silveyradas, a series of eighteen "Theological Dialogues" in verse, which is apparently the last work he put into clandestine cir-

Libro Quarto, fols. 34v-35r, 114r, 117r and 118v-122r; Silveyradas, Libro Quinto, fols. 6r, 85r and 98r-v; and Silveyradas, Libro Mudo, fols. 77r-80v, 82r-83r and 84v-87r).

88 Gómez Silveyra calls the series "my six books" in Silveyradas, Libro Quarto, fols. $1 \mathrm{r}$ and 200r; Libro Anteprimero, fols. 245v, 247v and 258r, and Libro Quinto, fol. $64 \mathrm{v}$. The year 1725 is marked on the six-volume set owned by Yeshiva University, as well as on the Libro Anteprimero in the Bibliotheca Rosenthaliana.

89 Silveyradas, Libro Mudo, fol. 220r-v, dated December 4, 1736; fol. 221r, dated March 10, 1737; fol. 253v, dated July 1737; fol. 278v, dated January 13, 1738, and fol. 282r, dated July 15, 1738.

90 Silveyradas, Libro Mudo, fols. 220r-221r.

91 Silveyradas, Libro Mudo, fols. 253v-282r. 
culation. ${ }^{92}$ Throughout the book, he imagines a debate among four speakers, namely "a wise Protestant minister having the chair, a learned Roman Apostolic Catholic, an erudite Mahometan Turk, and an unimpassioned Jew." ${ }^{93}$ The discussion in this interreligious council resembles a puppet play, insofar as it avoids individualizing the speakers and offers a stereotypical exchange of confessional standpoints. In the conversation, the Protestant clashes with the Catholic on papal authority and liberty of conscience, while the Muslim, who defends natural reason, ${ }^{94}$ forms a common front with the Jew when it comes to challenging the two Christians on the themes of the Trinity, the Incarnation, and the abrogation of Mosaic Law. The four speakers' standpoints do not develop in any way; they are as rigid in the end as they had been at the beginning, awaiting messianic reconciliation.

Since most of the eighteen dialogues are already included in previous volumes from the years $1720-1725,{ }^{95}$ Gómez Silveyra likely composed these debates with fictional non-Jews in the 1710s, shortly after La Croze invented his Sephardi Jew Moyse Aboab. The Silveyradas also stage two prose dialogues among the same four interlocutors, even introducing once a Confucian as the fifth member of the council. ${ }^{96}$

92 Silveyradas, Dialogos, fol. 71r, quotes an article on the freemasons in the Gazette of April 2, 1737; fol. 125r, mentions the Dutch Day of Fasting and Praying on March 26, 1732; and in fol. 327r, the author quotes his own Libro Mudo, which he had finished on July $15,1739$.

93 Silveyradas, Dialogos, fol. Ir.

94 Silveyradas, Libro Terzero, fol. 164r-v; Silveyradas, Libro Quinto, fols. 107r-v, 189r and 190r, and Silveyradas, Dialogos, fol. 275r.

95 The eighteen "Theological Dialogues" form a poetic cycle, as each one of them uses a different Spanish meter. For fifteen of them, parallel versions are extant in the Silveyradas, namely in Libro Quarto for nos. 11, 13, 14; in Libro Anteprimero for nos. 5, 7, 16; and in Libro Quinto for nos. 1-4, 6, 8, 12, 17, 18. All poems included in the Silveyradas are rewritten as monologues in the Ets Haim copy, whereas nos. 1 and 14 remain in dialogue form in the Yeshiva University copy. Only nos. 9, 10 (dated 1732), and 15 (in Portuguese) have no parallel in the Silveyradas.

96 Silveyradas, Libro Quinto, fols. 188v-193r, and Silveyradas, Libro Mudo, fols. $253 \mathrm{v}-278 \mathrm{v}$

SEFARAD, vol. 81:2, julio-diciembre 2021, págs. 449-475. ISSN: 0037-0894. https://doi.org/10.3989/sefarad.021-014 


\section{The interreligious dialogue as a fictional SURROGATE}

Until his old age, Gómez Silveyra kept inventing a sort of public interfaith talk that he had never encountered in social reality. His four thousand pages show him as a voracious reader of hundreds of specimens of the new literature, but while he occasionally prides himself on having confronted pastors and monks in debates, ${ }^{97}$ his anecdotes of such personal experiences all betray the presence of literary invention. Unlike the generations of Elijah Levita in the times of humanism, Menasseh ben Israel in the Dutch Golden Age, ${ }^{98}$ or Moses Mendelssohn during the later Enlightenment, the first half of the eighteenth century lacked appropriate venues for Jewish-Christian contacts, and intellectual transfers were mediated almost exclusively by the many publications that Christians were allowed to produce. Gómez Silveyra suffered from this injustice: "All can speak, because they all have a king who can defend them; only the Jew, for his sins, remains speechless." 99 Even in the Netherlands, keeping one's mouth closed about Christianity was the accepted price of toleration: "There is nothing more imprudent than if tolerated inhabitants give the rulers a reason to feel irritated." ${ }^{100}$ Gómez Silveyra curtailed his desire to confront Reverend Jacquelot with his critical thoughts: he feared, it seems, that this would have provoked a scandal of incalculable consequences. His status as a Jew did not allow him to reach out to Christians either orally or literarily: "Since I write truths, I have to hide them. I only let my Jews read, who know them already, and I cannot serve the others." ${ }^{01}$ If Gómez Silveyra, with his ideal loca-

${ }^{97}$ See, for example, Silveyradas, Libro Terzero, fols. 4v "Yo conosco comfesores que me lo comfesaron"; $57 \mathrm{v}$ "un doctorazo gravísimo que yo conosco ... me dixo ayer en la cara delante de sus parroquianos"; 101r "aturdí yo todo un convento"; Silveyradas, Libro Quarto, fol. 3r "Mons. Jacquelot ni otros muchos que conozco Jacquelotes"; and Silveyradas, Libro Quinto, fols. 63v "Llegó a Anveres a pocos años un estrangero franzés que nació en la China"; $34 \mathrm{r}$ "yo conozco / muchos letrados doctores"; 176v "Yo tengo un frayle mi amigo", and 182r "se los clavé ayer noche en la frente a un frayle que vino a visitarme."

98 Sina Rauschenbach, "Mediating Jewish Knowledge: Menasseh ben Israel and the Christian Respublica litteraria," Jewish Quarterly Review 102, 4 (2012) pp. 561-588.

99 Silveyradas, Libro Anteprimero, fol. 126r.

100 Silveyradas, Libro Segundo, fol. 544r.

101 Silveyradas, Libro Anteprimero, fol. 3r. 
tion in the center of Amsterdam, with his assured income and his unlimited leisure time, with his Spanish Catholic upbringing, his literary pedigree, and his fluency in French, with his ardent desire to read Christian books and to engage with their ideas, with his graphomaniacal urge to express himself provocatively-if such a man never dared to address his Christian neighbors in person or even by correspondence, what must we conclude about those Jews for whom language barriers, professional duties, or community concerns set much stricter limits on social contact?

Jonathan Israel's question of whether there was an Enlightenment movement among early-eighteenth-century Sephardim can only be answered if we distinguish strictly between cultural participation and social interaction. To Abraham Gómez Silveyra in Amsterdam and David Nieto in London, the pioneers of the Enlightenment among the Jews, we can extend the observations that Francesca Bregoli has formulated with respect to their younger contemporary, Joseph Attias (1672-1739) in Livorno. This "exceptional" man was a go-between connecting local Jewry with Enlightenment scientists, but he followed, according to Bregoli, a conscious "strategy of self-silencing" when it came to discussing religion with Christians. ${ }^{102}$ The way of European Jewry from early modernity to emancipation was "neither linear nor simple:" 103 it seems to have passed through a latency phase in which an intense intellectual appropriation of Enlightenment literature was possible with a minimum of direct debate. When intellectual debates were released from the elitist correspondences of scholars "into the journals and the coffeehouses," 104 this new public sphere did not immediately welcome Jews. On the contrary, formulating objections to Christian beliefs became much riskier at a time when any confidential word could be picked up by an expanding press that kept upholding certain speech taboos. Truth, wrote Gómez Silveyra, was silenced "by the inquisitors in some countries, and by the

102 Francesca BREgoli, Mediterranean Enlightenment: Livornese Jews, Tuscan Culture, and Eighteenth-Century Reform (Stanford, CA: Stanford University Press, 2014) pp. 43 and 56.

103 Bregoli, Mediterranean Enlightenment, p. 11.

104 Anthony Grafton, Worlds Made by Words: Scholarship and Community in the Modern West (Cambridge, MA: Harvard University Press, 2009) p. 180. 
'what will they say?' in others." 105 As the campaign against Jurieu had shown, even Amsterdam was home to a sort of "cruel Inquisition." 106 From a Jewish perspective, the proliferation of new press outlets had enhanced the control of expression rather than its freedom.

In sum, the literary imagination of Jewish-Christian communication in Gómez Silveyra's clandestine works did not reflect actual contacts; and exactly the same is true for contemporary Christian writers. "Paradoxically, Christians often preferred to engage with Jewish ideas and texts rather than with actual Jews themselves," according to David B. Ruderman. ${ }^{107}$ Gómez Silveyra mockingly pointed to the abundance of fake infidels in theological literature. Among the published epistolary of Richard Simon, there is a twenty-page-long letter that the rabbinate of Amsterdam is said to have sent in 5446 (1686) to Jurieu, thanking him for his messianic pronouncements. The fictional "rabbis" list in their letter a number of biblical prophecies that would have allowed Jurieu to make his conclusions even stronger. One may see this piece as a Catholic satire on the Judaizing tendencies among the Huguenots, but Gómez Silveyra read it as Simon's pretext to express a secret agreement with Jurieu on his millenarian convictions by using the Amsterdam rabbis as his mouthpiece: "Father Simon laid out in the name of my rabbis all the truths that he did not dare to express in his own name because of the 'what will they say?' There are many more examples of this kind." 108

Having perfectly grasped the function of the fictional Jew, Gómez Silveyra similarly suspected the authenticity of the free-thinking Jewish interlocutor that an anonymous abbé-in fact, Jean-Baptiste de Chèvre-

105 Silveyradas, Libro Quinto, fol. 171r.

106 Silveyradas, Libro Terzero, fol. 210v, and Silveyradas, Libro Quinto, fols. 137v and 185v: "La cruel Ynquisición del 'qué dirán' en todas partes domina."

107 David B. Ruderman, Connecting the Covenants: Judaism and the Search for Christian Identity in Eighteenth-Century England (Philadelphia: University of Pennsylvania Press, 2007) p. 2.

108 Silveyradas, Libro Segundo, fols. 537v-538r, on the "Lettre des Rabbins des deux synagogues d'Amsterdam, à Mr. Jurieu, traduit de l'Espagnol. Suivant la copie imprimée à Amsterdam chès Joseph Athias," which had been printed in Richard Simon, Lettres choisies (Amsterdam: Louis de Lorme, 1700) pp. 301-320. This piece pretends to be a reply to Jurieu's letter "À la Nation des Juifs" ("Letter to the Jewish People"), which starts the Accomplissement des prophéties. See FuKs-Mansfeld, "Une rencontre en exil," p. 66. 
mont-inserted into his dialogue Le christianisme éclairci (Enlightened Christianity, 1700):

I suppose that no Jew has ever told these things to him. The Jew is the abbé himself, who spoke as a wise and as a Jew. It is a great misfortune that we cannot speak. The accursed Inquisition that is called "what will the fools say?" closes the mouth of the wise. One has to hide away the truth or talk in accordance with the dominant lies; and if ever a man becomes disillusioned and wants to say the truth, he needs to pretend that someone else is speaking. ${ }^{109}$

This rhetorical exercise brought forth Moyse Aboab, Aaron Monceca, and the spurious crowd of Jews who debate with Christians in early Enlightenment literature. Likewise, the stylized Huguenots with whom Gómez Silveyra discusses religion are the products of a literary genre that, far from reflecting actual dialogue, was a compensation for the absence of it, as well as for Jewish powerlessness in general. Abraham Gómez Silveyra claimed to turn Judaism, in spite of its political impotence, into a self-conscious participant, even a judge, in the concert of religious doctrines. But he could utter this claim only in his private literary fantasies and for an exclusively Jewish audience. This is why he obsessively evokes, time and time again, the thoroughly unreal situation in which adherents of different creeds publicly engage in a friendly dialogue. I do not know what I find more remarkable about this writer: his total immersion in the thought and sources of a foreign diaspora, or his social isolation from its authors, who implored him to speak and at the same time consigned him to silence.

Recibido: $11 / 08 / 2021$

Aceptado: 21/10/2021

109 Silveyradas, Libro Quinto, fol. 91r, on [Jean-Baptiste DE ChĖvremont], Le christianisme éclairci, sur les differens du temps, en matiere de quietisme, par l'abbé de *** (Amsterdam: Gallet, 1700). 
